\title{
Leadership Behaviour, Entrepreneurial Orientation and Organisational Performance in Malaysian Small and Medium Enterprises
}

\author{
Azizah Hashim ${ }^{1}$, Che Mohd Zulkifli Che Omar², Mohd Sahandri Gani Hamzah ${ }^{3}$, Azmi Umar ${ }^{1}$ \\ ${ }^{1}$ Faculty of Management \& Economics, Sultan Idris Education University (UPSI), Malaysia \\ ${ }^{2}$ Associate Professor, Faculty of Management \& Economics, Sultan Idris Education University (UPSI), Malaysia \\ ${ }^{3}$ Professor, Chancellor Office of Academic \& International, Sultan Idris Education University (UPSI), Malaysia \\ Correspondence: Azizah Hashim, Faculty of Management \& Economics, Sultan Idris Education University \\ (UPSI) 35900 Tanjung Malim, Perak, Malaysia.
}

Received: July 14, 2018

doi:10.5539/ibr.v11n9p37
Accepted: August 7, $2018 \quad$ Online Published: August 10, 2018

URL: https://doi.org/10.5539/ibr.v11n9p37

\begin{abstract}
The purpose of this paper is to discuss the organizational performance and entrepreneurial orientation of Malaysian Small and Medium Enterprises (SMEs). Literature has shown that leadership and entrepreneurial orientation are important for organizational performance but still inadequate. Thus, this investigation hopes to close this gap in the literature and contribute to a new understanding of relationships between leadership and organizational performance, and entrepreneurial orientation served as a mediator. This study comprised a sample of owners or managers in the manufacturing and service sectors of SMEs located in Kuala Lumpur and Selangor, as their largest representation of SME establishments and significant contributions to Malaysia economy. A cross-sectional research design was used to examine the relationships between leadership behavior, entrepreneurial orientation and organizational performance among SMEs. The respondent's lists were sought from the SME Corp. Malaysia at http://www.smecorp.gov.my and http://www.smeinfo.com.my. Data were gathered based on a mailed questionnaire and personal administered questionnaires. The findings indicate that entrepreneurial orientation acted as a partial mediator in the relationship between leadership behavior and organizational performance. Transformational leadership and transactional leadership were found to have a significant relationship with entrepreneurial orientation and organizational performance of SMEs. An important implication of this research indicated that both transformational and transactional leadership behavior positively increased the individual outcome and lead to higher organizational performance.
\end{abstract}

Keywords: leadership behavior, transformational leadership, transactional leadership, entrepreneurial orientation, organizational performance, SMEs

\section{Introduction}

In Malaysia, SMEs represent as the backbone of the local economies and SMEs be recognized as engines of economic growth behind industrial development (Amin et al., 2016; Abdullah \& Rosli, 2016). SMEs accounted for $99.2 \%$ of all business establishments, contributed 32\% of real gross domestic product (GDP) and 19\% of export (Zuraidah \& Gerry, 2010; National SME Development Council, 2010). The characteristics and determinants of the performance of SMEs have been a large discussion among scholars (Arham, 2015; McKelvie $\&$ Wiklund, 2010). SMEs facing few weaknesses such as insufficient workers, insufficient financial support, lack of educational background and less of expertise and professional management team (Amin et al., 2016; Samad, 2007; Saleh \& Ndubisi, 2006; Abu Bakar et al., 2006; Mohd Aris., 2006). To enhance the development of SMEs, full efforts are continuously being made seriously by governments (Al-Dhaafri, Al-Swidi \& Yusoff, 2016; Dzomonda et al., 2017; Hayat et al., 2011)

This objective of this research is to examine the impact of SMEs performance in Malaysia from the context of leadership behavior and the entrepreneurial orientation (EO). Leadership and EO are already known as crucial components for organization achievement (Arshad et al., 2016; Gul et al., 2012; Hannay, 2009; Wang, 2008; Yang, 2008). Strategic direction to the workers will motivate them to achieve organizational performances (Luu, 2017).

Leadership is vital to enhance organization achievement as leaders are responsible for strategic firms' goal (Yang, 
2016). Hence, top management is accountable to the stakeholders in producing and creating the best products and services through sufficient resources allocated by companies (Madanchian et al., 2016; Ahmad et al., 2014). On the other hand, the organization needs to give full attention to evolving entrepreneurial orientation which portrayed them differently from their rivals in the market.

Leadership and EO are crucial factors that are needed to be upgraded and strengthen the organizational performance and to stimulate entrepreneurs of SMEs for better equip and well prepared to be more competitive in order to transform Malaysia to become a high - income developed nation with a knowledge-based economy by the year 2020 .

\section{Problem Statement}

SMEs play a focal role in the economy and social landscape of Malaysia and are viewed as critical pillars of the country (Radam, Abu \& Abdullah, 2008). However, SMEs in Malaysia still faces difficulty such as lack of resources, inadequate knowledge and insufficient of managerial skills (Lim, 2016; Ahmad \& Seet, 2009; Alkahtani, Abu-Jarad, Sulaiman \& Nikbin, 2011; Hoq, Ha \& Said, 2009; Saleh \& Ndubisi, 2006). The lack of managerial skills was one of major limitation and reduced the ability of SMEs to improve their productivity and performance of the firm (Abe et al., 2012; SME Corporation Malaysia, 2014). Malaysian SMEs contributed about 32\% (NSDC, 2010) only, however, Singapore and Thailand recorded much higher, 49\% and 38\% respectively. Therefore, there was a challenge for the leaders of SMEs have to equip with a number of expertise such as management and leadership skills to improve the performance and mitigate setbacks and failure.

Even though researchers and practitioners have a great discussion and interest in the topics of leadership and EO (Arshad et al., 2016; As-Sadeq \& Khoury, 2006; Ling et al., 2008; Lo et al., 2010, James et al., 2016; Moreno \& Casillas, 2008; Rauch et al., 2009; Wiklund, 1999), the arguments have to be liable in considering closely whether there is a relationship between leadership and $\mathrm{EO}$ on the one hand and organisational performance on the other hand. A very few studies have been focused and conducted to investigate the relationship between the three variables simultaneously (Arham, 2014; Yang, 2008; Todorovic \& Schlosser, 2007). Thus, the investigation of an entrepreneurial orientation as a mediator in the leadership-performance relationship will contribute to a new understanding of relationships between leadership and organizational performance of SMEs in Malaysia.

Previous studies found that SMEs in Malaysia still lack or limited understanding of leadership (Rahim et al., 2016: Abdul Aziz et al., 2013; Mohd Sam et al., 2012; Hashim et al., 2012). Thus, this investigation of the forms of leadership behavior in SMEs in Malaysia hopes to close this gap in the literature on SMEs.

\section{Literature Review and Hypotheses Development}

\section{Transformational leadership and Organisational Performance}

Previous researchers have displayed the existing of a strong correlation between transformational leadership and organizational performance. This strong correlation was proved by Avolio (1999) and Bass (1998) with numerous different measures. However, Dvir et al. (2002) suggested a better achievement from followers comes from transformational leaders than other types of leadership. Ramey (2002) agreed that a positive and moderate correlation was found between transformational leadership and the job satisfaction. A study in Pakistan found a positive correlation between the transformational leadership style and SMEs performance and a weak positive correlation between transactional leadership style and SMEs performance (Naeem \& Tayyeb, 2011). Zumitzavani and Udchachone (2014) claimed that a transformational leadership style has a positive relationship with organizational performance in the hospitality industry in Thailand.

\section{H1: Transformational leadership has a significant effect on Organisational Performance.}

\section{Transformational Leadership and Entrepreneurial Orientation}

Past studies reveal that innovativeness, risk-taking, and proactiveness are the main traits of entrepreneurial or intrapreneurial (Miller, 1983; Shirokova et al., 2016). Moriano et al., 2014 urged that the managers who possess a high level of transformational leadership traits led to an increase of the employees' level of intrapreneurial activities. Politis and Harkiolakis (2008) stated that transformational leadership is strongly positively related to the innovation dimension of entrepreneurial orientation compared to transactional leadership. In addition, it was found that transformational and transactional leadership equally affected the risk-taking and proactiveness dimensions.

\section{H2: Transformational leadership has a significant effect on the entrepreneurial orientation}

\section{Transactional Leadership and Organisational Performance}


Amirul and Daud (2012) examined the relationship between transactional leadership and leadership outcomes in 325 companies in the context of SMEs in Malaysia. The result stated that transactional leadership is positively related to organizational performance. Arham (2014) also found that transactional leadership has a positive relationship with organizational outcomes in Malaysian SMEs manufacturing and service sector. This is in line with a study done by Abdul Aziz et al. (2013) urged a significant relationship between transactional leadership and performance in the service sector.

\section{H3: Transactional leadership has a significant effect on organizational performance}

\section{Transactional Leadership and Entrepreneurial Orientation}

Kwasi (2015) remarks that transactional leaders are more task-or goal-oriented than people-oriented. On that note, transactional leaders define objectives and set expectations from each employee prior to the execution of the task (Martin, 2015). Businesses in this 21st century are exposed to a plethora of challenges such as stiff competition, short product life cycles among others all emanating from globalization. According to Panagopoulos and Avlonitis (2010), leadership style is a crucial requirement if a firm attempted to adopt an EO strategy successfully. A study by Nahavandi (2006) indicated that a transactional leader creates an EO atmosphere in the organization through the concept of exchange.

\section{H4: Transactional leadership has a significant effect on entrepreneurial orientation}

\section{Entrepreneurial Orientation and Organisational Performance}

The measurement of EO commonly used by scholars was developed by Covin and Slevin (1989), based on the research done by Khandwalla (1977) and Miller (1983). This scale, which consists of three dimensions, innovation, proactiveness, and risk-taking. The measurement of EO was adopted by numerous studies (Becherer \& Maurer, 1997; Dickson \& Weaver, 1997; Naman \& Slevin, 1993; Steensma et al., 2000). Lumpkin and Dess (1996) added another two dimensions; competitive aggressiveness and autonomy, in the existing of measurement of EO. However, this study used three dimensions of entrepreneurial orientations; proactiveness, innovativeness, and risk-taking based on Covin and Slevin (1989). Lumpkin and Dess (2001) demonstrated that the dimensions of EO led to market growth. Past studies at empirical level have shown a positive relationship between entrepreneurial orientation and firm performance, e.g. a longitudinal study has found that entrepreneurial orientation to have a long-term effect on growth and financial performance of small businesses (Wiklund \& Sheperd, 2003).

Therefore, it is suggested that firms may gain benefit from adopting an EO. Such firms innovate frequently while taking risks in their product market strategies (Miller \& Friesen, 1978). Efforts to anticipate demand and aggressively position new product/service offerings often result in a strong performance (Ireland et al., 2003). Hence, the study of EO especially on Covin and Slevin (1989) dimensions, needs more studies to prove there is a relationship between $\mathrm{EO}$ and business performances.

\section{H5: Entrepreneurial orientation has a significant effect on organisational performance}

\section{Entrepreneurial Orientation, Transformational Leadership and Organizational Performance}

Transformational leaders discover and expand shared values and empower others (Owen et al., 2004; Ozaralli, 2003), influenced subordinates to produce better quality and quantity of work, and being a creative problem solver of employees (Limsila \& Ogunlana, 2008). This is a procedure for improving and changing employees by increasing motivation, building commitment, and empowering them to achieve organizational performance (Yulk, 2010). In other words, transformational leaders have the ability to boost the commitment of employees through shared values and shared vision (Sadler, 2003). Transformational leaders change things by crafting the vision and by influencing followers to buy into the vision (Lussier \& Achua, 2007). In addition, transformational leaders focus on the organization and direct follower commitment toward organizational goals.

Studied by Arham (2014) involved 390 respondents from service and manufacturing SMEs in Malaysia also found that transformational leadership has a significant relationship with EO that related to growth and profitability of the organization. Hassim et al. (2011) proposed that appropriate behavior of the leaders is an important factor of a firm's strategy for enhancing its entrepreneurial stance.

H6: Entrepreneurial orientation has mediates the relationship between transformational leadership and organizational performance

\section{Entrepreneurial Orientation, Transactional Leadership and Organizational Performance.}

Transactional leadership suggested that a leader has to observe behavior which seeks to supervise subordinates to assure strength in the workplace and to assure the management procedures are followed by subordinates (Bass, 
1985). There are mixed findings on leadership behavior and EO in previous research. Yang (2008) stated that transactional leadership has a small positive relationship with EO. Contrary, a study was done by Eyal and Kark (2004) found that there is no significant relationship between transactional leadership and EO. They declared that managers or leaders practice or adopt transactional leadership behavior are less inclined to be more proactiveness or innovativeness.

Meanwhile, Jung et al. (2008) insisted that leaders have a direct influence on organizational performance through their characteristics and behavior and indirect influence through the strategic choices they make. EO is essential elements as a firm's strategic choice that captures the specific entrepreneurial aspects of decision-making styles, methods and practices (Wiklund \& Shepherd, 2005) and it is a key to enhance organizational performance (Covin \& Slevin, 1989; Lumpkin \& Dess, 1996). In the context of SMEs in Malaysia, Arham et al. (2015) demonstrated that transactional leadership has a significant relationship to EO, and EO has a direct significant relationship to growth and profitability in manufacturing and services sector.

H7: Entrepreneurial orientation has mediates the relationship between transactional leadership and organizational performance.

\section{Methodology}

A cross-sectional research design was employed in this study where a data was collected at a given point of time (Sekaran \& Bougie, 2013; Kumar et al., 2013). A quantitative research approach was applied which commonly used in social sciences studies (Keng et al., 2013; Shukri \& Mahmood, 2014). Manufacturing and services sector located in Kuala Lumpur and Selangor were considered as a population of this study. Simple random sampling was employed and the sample size of 384 is enough for population up to 1 million were used (Sekaran \& Bougie, 2010). The unit of analysis for this study is at the organizational level which involved the entire SMEs owners or managers. The data collected were analyzed and interpreted using the Statistical Package for Social Science (SPSS) to analyze the demographic profiles of the respondents meanwhile, and Structural Equation Modelling (SEM)-AMOS 22.0 software package to test the inter-relationships between constructs of the hypothesized model.

\section{Measurement}

All variables were measured using 10 points Likert scale ranging from 1 (Strongly Disagree) to 10 (Strongly Agree) because having more scale points able to reduce skewness, and has the smallest kurtosis and close to normal. (Leung, 2011). Section 1, contains the measurements for leadership behavior that were adopted from the Multifactor Leadership Questionnaire (MLQ) developed by Bass and Avolio (2004). The researchers have obtained the questionnaire from Yogeswaran (2015) with a permission from Mind Garden to use the MLQ Leader $5 \mathrm{X}$ short form that consists of 45 items. However, only 32 items representing transformational and transactional leadership were included in the questionnaire.

Section 2, measured the EO construct which in this study comprises the initial factors developed by Miller (1983); innovativeness, pro activeness and risk-taking. The measurement of these factors was adopted from Covin and Slevin (1989) and Wang (2008). The EO scale that consists of these three factors is the most widely used measure of EO in entrepreneurship literature ( Runyan et al., 2012). Four items measured innovativeness, four items measure proactiveness, and three items measure risk-taking. Section 3 measures the organizational performance construct through growth and profitability, which was adopted from Matzler et al. (2008), Tan (2007), and Arham (2014). Section 4, asked for demographic information and business background of the respondents.

\section{Global Fitness of Indexes}

The global fitness index can be determined by the absolute, incremental, and parsimonious fit; factor loading can be assessed by the value of standardized estimates, and construct correlations was identified by the value of standardized correlations. The recommended value for the factor loadings is 0.60 (Hair et al., 2010; Awang, 2015; Ali et al., 2018). Meanwhile, the recommended value for the construct reliability is 0.70 (Hair et al. 2010; Nunally \& Bernstein, 1994).

Hair, Babin \& Barry (2017) suggested the study should report at least one index from the category of Absolute Fit, Incremental Fit, and Parsimonious Fit in order to validate construct validity. From Table 1, all fitness indexes have achieved the required level. Thus the measurement model has achieved the construct validity (Awang, 2015). 
Table 1. Global Fitness of Indexes

\begin{tabular}{llll}
\hline Name of category & Name of index & Index value & Comments \\
\hline Absolute fit & RMSEA & 0.032 & The required level is achieved \\
Incremental fit & CFI & 0.966 & The required level is achieved \\
& TLI & 0.964 & The required level is achieved \\
Parsimonious fit & IFI & 0.966 & The required level is achieved \\
\hline
\end{tabular}

\section{Result}

In this study, a total of 1,700 questionnaires were distributed to the respondents via postal mail and they were given two months to complete and return the questionnaires to the researcher. From the questionnaires distributed, only $435(25.58 \%)$ were received and $401(23.58 \%)$ set of questionnaires are used for further analysis. The 34 questionnaires were not used because they were incomplete. The profiles of the respondents based on gender, age, race, industry, level of education, the tenure of business, a total of employees and total of sales turnover were illustrated in Table 2.

Table 2. Profiles of Respondents

\begin{tabular}{llcc}
\hline & & Frequency & Percent \\
\hline Industry & Manufacturing & 146 & 36.4 \\
Gender & Service \& Other Sectors & 224 & 55.9 \\
& Male & 218 & 54.4 \\
& Female & 183 & 45.6 \\
& Secondary Education & 30 & 7.5 \\
& Certificate/Diploma & 37 & 9.2 \\
& Degree & 232 & 57.9 \\
& Master & 60 & 15.0 \\
& PhD/Doctorate & 39 & 9.7 \\
\hline
\end{tabular}

\section{Pooled Confirmatory Factor Analysis (CFA)}

The pooled CFA is regarded as the method of choice when assessing the measurement model because it can avoid the identification problem if construct contains less than four items per construct. Apart from that, the demonstration results from pooled CFA is seemed more comprehensive than the other ones since it considered all constructs in one model (Kashif et al., 2015; Awang, Afthanorhan \& Asri., 2015). Figure 1 below, shows the results of factor loadings, construct correlations and fitness indexes. By inspecting the results of fitness indexes, all fitness indexes are satisfied since the parsimonious fit (Chisq/df $=1.378<3.0)$; absolute fit $(\mathrm{RMSEA}=0.031$ $<0.08)$; and incremental fit $(\mathrm{CFI}=0.967$, IFI $=0.967$, and TLI $=0.965>0.90)$. The factor loading also was satisfied since its value is greater than the recommended value of 0.6. However, only one item (JJ8) from transformational leadership was detected carried poor factor loading $(0.43)$.

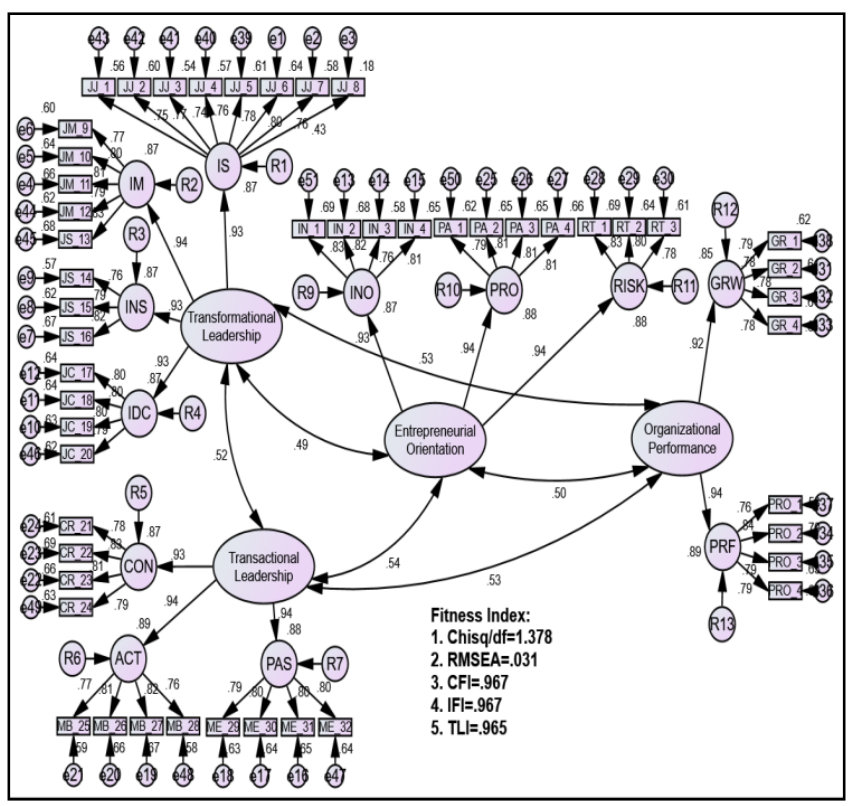

Figure 1. First Model 


\section{Reliability and Validity}

In terms of construct reliability and validity, this model was determined by the Composite Reliability (CR) and Average Variance Extracted (AVE) as shown in Table 3. The Composite Reliability (CR) and Average Variance Extracted (AVE) are satisfied in that above 0.70 and 0.50 respectively (Nunnally \& Bernstein, 1994; Lowry \& Gaskin, 2014)

Table 3. Composite Reliability and Average Variance Extracted Results

\begin{tabular}{lcc}
\hline & CR & AVE \\
\hline Transformational Leadership & 0.964 & 0.870 \\
IS & 0.899 & 0.614 \\
IM & 0.888 & 0.614 \\
INS & 0.805 & 0.580 \\
IDC & 0.856 & 0.597 \\
Transactional Leadership & 0.955 & 0.877 \\
CON & 0.865 & 0.616 \\
ACT & 0.854 & 0.594 \\
PAS & 0.862 & 0.610 \\
Entrepreneurial Orientation & 0.955 & 0.877 \\
INO & 0.866 & 0.619 \\
PRO & 0.869 & 0.624 \\
RISK & 0.819 & 0.601 \\
Organizational Performance & 0.928 & 0.865 \\
GRW & 0.847 & 0.581 \\
PRF & 0.864 & 0.613 \\
\hline
\end{tabular}

Note. IS=Idealised Stimulation, IM = Idealised Motivation, INS = Idealised Influence, IDC $=$ Individual Consideration, $\mathrm{CON}=$ Contingent Reward, ACT=Management-by-exception active), PAS $=$ Management-by-exception (passive), INO = Innovativeness, PR0 = Proactiveness, RISK= Risk Taking, GRW=Growth, PRF $=$ Profitability

\section{Discriminant Validity}

Based on Table 4, it is observed that the correlation between all constructs is less than 0.85 (Hair et al. 2010; Kline, 2015). Moreover, the value of AVE squared (bold value) is higher than the correlation construct in its row and column (Fornell \& Larcker, 1981). Therefore, it is concluded that the discriminant validity of the model is satisfied, and all constructs remain in the model suitable for the estimation.

Table 4. Discriminant Validity Results

\begin{tabular}{lcccc}
\hline \multicolumn{1}{c}{ Construct } & $\begin{array}{c}\text { Transformational } \\
\text { Leadership }\end{array}$ & $\begin{array}{c}\text { Transactional } \\
\text { Leadership }\end{array}$ & $\begin{array}{c}\text { Entrepreneurial } \\
\text { Orientation }\end{array}$ & $\begin{array}{c}\text { Organizational } \\
\text { Performance }\end{array}$ \\
\hline $\begin{array}{l}\text { Transformational } \\
\text { Leadership }\end{array}$ & $\mathbf{0 . 9 3 3}$ & & & \\
$\begin{array}{l}\text { Transactional } \\
\text { Leadership }\end{array}$ & 0.52 & $\mathbf{0 . 9 3 6}$ & $\mathbf{0 . 9 3 6}$ & $\mathbf{0 . 9 3 0}$ \\
$\begin{array}{l}\text { Entrepreneurial } \\
\text { Orientation }\end{array}$ & 0.49 & 0.54 & 0.50 & $\mathbf{0 . 5 3}$ \\
$\begin{array}{l}\text { Organizational } \\
\text { Performance }\end{array}$ & 0.53 & 0.53 & & \\
\hline
\end{tabular}

\section{Assessment of Normality}

Table 5 below shows the assessment of normality distribution. The measure of skewness reflects the normality assessment for every item. The absolute value of skewness 1.0 or lower indicates the score is normally distributed (Awang, 2015). However, the absolute value of skewness below than 1.5 is still acceptable (Hair et al. 2010). Therefore, it can be concluded that the normality test is achieved. Moreover, the critical ratio of skewness is suggested valid when the value is below than 8.0. As is shown in the table, the value of the critical ratio of skewness is acceptable. Other than that, the multivariate of kurtosis also can be determined to assess the normality distribution. According to Awang (2015), the acceptable results for multivariate is under 50. In this case, multivariate of kurtosis is satisfied and suitable for the parametric method as a covariance-based Structural Equation Modelling. 
Table 5. Normality Results

\begin{tabular}{|c|c|c|c|c|c|c|}
\hline Variable & Min & $\max$ & skew & c.r. & kurtosis & c.r. \\
\hline IN_1 & 2.000 & 8.000 & -.161 & -1.313 & .091 & .372 \\
\hline PA_1 & 2.000 & 8.000 & -.180 & -1.469 & -.042 & -.173 \\
\hline CR_24 & 2.000 & 8.000 & .056 & .461 & -.044 & -.181 \\
\hline MB_28 & 2.000 & 7.000 & .057 & .470 & -.127 & -.519 \\
\hline ME_32 & 2.000 & 8.000 & .071 & .579 & .050 & .203 \\
\hline JC_20 & 1.000 & 6.000 & -.121 & -.989 & -.243 & -.995 \\
\hline JS_13 & 2.000 & 8.000 & -.217 & -1.770 & .080 & .327 \\
\hline JM_12 & 1.000 & 8.000 & .106 & .863 & .321 & 1.311 \\
\hline JJ_1 & 2.000 & 8.000 & -.138 & -1.126 & .334 & 1.366 \\
\hline JJ_2 & 1.000 & 8.000 & .045 & .367 & .237 & .970 \\
\hline JJ_3 & 3.000 & 9.000 & -.073 & -.593 & -.188 & -.767 \\
\hline JJ_4 & 3.000 & 9.000 & -.005 & -.041 & -.055 & -.225 \\
\hline JJ_5 & 2.000 & 8.000 & -.094 & -.772 & .008 & .031 \\
\hline GR_1 & 3.000 & 9.000 & .051 & .413 & .014 & .057 \\
\hline PRO_1 & 2.000 & 7.000 & -.006 & -.052 & -.107 & -.437 \\
\hline PRO_4 & 1.000 & 6.000 & .099 & .806 & -.209 & -.853 \\
\hline PRO_3 & 1.000 & 7.000 & .294 & 2.405 & .239 & .978 \\
\hline PRO_2 & 3.000 & 10.000 & .141 & 1.152 & .202 & .825 \\
\hline GR_4 & 1.000 & 8.000 & .069 & .565 & .083 & .341 \\
\hline GR_3 & 1.000 & 8.000 & .093 & .761 & .130 & .533 \\
\hline GR_2 & 2.000 & 8.000 & .016 & .128 & .976 & 3.988 \\
\hline RT_3 & 2.000 & 8.000 & .167 & 1.368 & .076 & .313 \\
\hline RT_2 & 2.000 & 8.000 & -.120 & -.977 & -.080 & -.328 \\
\hline RT_1 & 3.000 & 6.000 & -.201 & -1.646 & .114 & .465 \\
\hline PA_4 & 2.000 & 7.000 & -.062 & -.510 & -.190 & -.775 \\
\hline PA_3 & 1.000 & 5.000 & -.146 & -1.197 & -.214 & -.873 \\
\hline PA_2 & 1.000 & 5.000 & -.137 & -1.119 & .250 & 1.022 \\
\hline CR_21 & 3.000 & 8.000 & .029 & .234 & -.262 & -1.071 \\
\hline CR_22 & 2.000 & 8.000 & .058 & .477 & .017 & .069 \\
\hline CR_23 & 2.000 & 8.000 & .156 & 1.276 & .125 & .510 \\
\hline MB_25 & 2.000 & 7.000 & .161 & 1.319 & -.250 & -1.023 \\
\hline MB_26 & 3.000 & 8.000 & .075 & .611 & -.269 & -1.099 \\
\hline MB_27 & 2.000 & 6.000 & .072 & .588 & .037 & .150 \\
\hline ME_29 & 3.000 & 9.000 & -.020 & -.163 & -.193 & -.789 \\
\hline ME_30 & 4.000 & 9.000 & .254 & 2.078 & -.344 & -1.407 \\
\hline ME_31 & 1.000 & 8.000 & -.155 & -1.268 & .271 & 1.109 \\
\hline IN_4 & 1.000 & 5.000 & -.109 & -.889 & -.038 & -.157 \\
\hline IN_3 & 3.000 & 9.000 & .000 & .001 & .008 & .034 \\
\hline IN_2 & 2.000 & 7.000 & -.168 & -1.373 & -.234 & -.958 \\
\hline JC_17 & 3.000 & 7.000 & .031 & .252 & .304 & 1.244 \\
\hline JC_18 & 2.000 & 8.000 & -.056 & -.459 & .089 & .362 \\
\hline JC_19 & 1.000 & 6.000 & -.085 & -.692 & -.231 & -.943 \\
\hline JS_14 & 1.000 & 7.000 & -.108 & -.884 & .049 & .199 \\
\hline JS_15 & 1.000 & 6.000 & -.218 & -1.781 & .049 & .198 \\
\hline JS_16 & 1.000 & 7.000 & -.240 & -1.959 & .540 & 2.209 \\
\hline JM_9 & 1.000 & 7.000 & -.113 & -.926 & -.064 & -.263 \\
\hline JM_10 & 3.000 & 9.000 & .134 & 1.099 & -.200 & -.819 \\
\hline JM_11 & 1.000 & 8.000 & -.245 & -2.003 & .263 & 1.077 \\
\hline JJ_7 & 2.000 & 8.000 & -.133 & -1.088 & .140 & .573 \\
\hline JJ_6 & 2.000 & 8.000 & -.121 & -.987 & .073 & .299 \\
\hline Multivariate & & & & & 7.259 & 1.008 \\
\hline
\end{tabular}

\section{Testing Mediation}

Figure 2 shows the standardized results. The standardized often used in assessing the mediation effect and measurement model during performing the pooled CFA. This is because the standardized estimates help the researchers to make interpretation easily. The value from standardized estimates would fall in the range value between 0 to 1 , which making it easy for comparison purpose. 


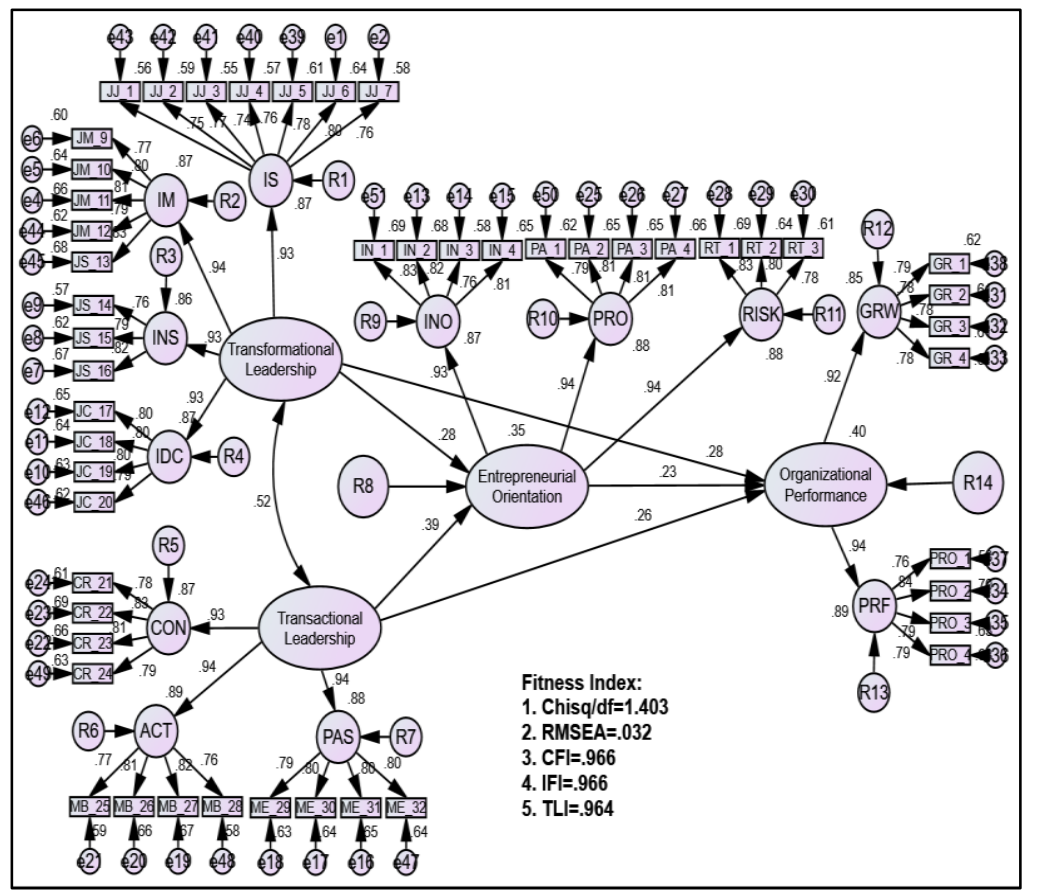

Figure 2. Standardized Estimates

\section{Regression Weight}

Table 6 shows the regression weight for each path analysis that has been proposed in the research hypotheses. From the table, it is clearly shown that all constructs have a significant contribution towards its respective endogenous constructs. By looking at the estimated value, transformational leadership has the highest positive contribution towards the organizational performance followed by transactional leadership and EO. Specifically, the interpretation for each effect as follows:

Table 6. Regression Weight

\begin{tabular}{|c|c|c|c|c|c|c|c|}
\hline & & & Estimate & S.E. & C.R. & $\mathbf{P}$ & Result \\
\hline $\begin{array}{l}\text { Entrepreneurial } \\
\text { Orientation }\end{array}$ & $<---$ & $\begin{array}{l}\text { Transformational } \\
\text { Leadership }\end{array}$ & .288 & .059 & 4.864 & $* * *$ & Significant \\
\hline $\begin{array}{l}\text { Entrepreneurial } \\
\text { Orientation }\end{array}$ & $<---$ & $\begin{array}{l}\text { Transactional } \\
\text { Leadership }\end{array}$ & .376 & .059 & 6.430 & $* * *$ & Significant \\
\hline $\begin{array}{l}\text { Organizational } \\
\text { Performance }\end{array}$ & $<---$ & $\begin{array}{l}\text { Entrepreneurial } \\
\text { Orientation }\end{array}$ & .199 & .054 & 3.678 & $* * *$ & Significant \\
\hline $\begin{array}{l}\text { Organizational } \\
\text { Performance }\end{array}$ & $<--$ & $\begin{array}{l}\text { Transformational } \\
\text { Leadership }\end{array}$ & .257 & .055 & 4.686 & $* * *$ & Significant \\
\hline $\begin{array}{l}\text { Organizational } \\
\text { Performance }\end{array}$ & $<---$ & $\begin{array}{l}\text { Transactional } \\
\text { Leadership }\end{array}$ & .220 & .054 & 4.057 & $* * *$ & Significant \\
\hline
\end{tabular}

\section{Bootstrapping Approach}

The use of a mediation model with bootstrap is available in AMOS software. This study used bootstrap Maximum Likelihood Estimator with 1,000 replications to produce consistent and unbiased results (Bollen \& Bainter, 2014). The result for bootstrapping estimates and p-value was obtained by the application of Amos output. From the Table 7, the regression weight estimate for indirect effect is 0.063 . The probability of getting a bootstrap p-value for indirect effect is 0.001 . What it means is that the regression weight for EO as mediator construct is significant at 0.001 level, hence, the hypothesis (H6) that EO has mediates the relationships between Transformational Leadership and Organizational Performance is duly supported. 
Table 7. The result of Direct and Indirect Effect (Transformational Leadership, Entrepreneurial Orientation, and Organizational Performance)

\begin{tabular}{lcc}
\hline & Indirect Effect & Direct Effect \\
\hline Bootstrapping Estimate & 0.063 & 0.284 \\
Bootstrapping P-Value & 0.001 & 0.002 \\
Result & Significant & Partial Mediation \\
Type of Mediation & & Significant \\
\hline
\end{tabular}

Table 8. The result of Direct and Indirect Effect (Transactional Leadership, Entrepreneurial Orientation and Organizational Performance)

\begin{tabular}{lcc}
\hline & Indirect Effect & Direct Effect \\
\hline Bootstrapping Estimate & 0.088 & 0.257 \\
Bootstrapping P-Value & 0.001 & 0.002 \\
Result & Significant & Significant \\
Type of Mediation & & Partial Mediation
\end{tabular}

Type of Mediation

Partial Mediation

The result for bootstrapping estimates and p-value was obtained by the application of Amos output. From the Table 8 , the regression weight estimate for indirect effect is 0.088 . The probability of getting a bootstrap p-value for indirect effect is 0.001 . What it means is that the regression weight for $\mathrm{EO}$ as mediator construct is significant at 0.001 level, hence, the hypothesis (H7) that Entrepreneurial Orientation has mediates the relationships between transactional leadership and organizational performance is duly supported. Furthers, to explain more about the type of mediation, the result for direct effect is examined. The regression weight for direct effect is 0.257 . The probability of getting bootstrap p-value for direct effect is 0.002 (p-value $<0.05$ ). Therefore, it can be concluded that the type of mediation for this model is Partial Mediation because the significant effect existed in the direct effect.

The summary of hypotheses testing as shown in Table 9.

Table 9. Summary of Hypotheses Testing

\begin{tabular}{lc}
\hline \multicolumn{1}{c}{ RESEARCH HYPOTHESES } & RESULTS \\
\hline HI : Transformational leadership has a significant effect on organizational performance & Supported \\
H2 : Transformational leadership has a significant effect on entrepreneurial orientation & Supported \\
H3 : Transactional leadership has a significant effect on organizational performance & Supported \\
H4 : Transactional leadership has a significant effect on entrepreneurial orientation & Supported \\
H5 : Entrepreneurial orientation has a significant effect on organizational performance & Supported \\
H6 : Entrepreneurial orientation has mediates the relationships between transformational & Supported \\
leadership and organizational performance & Supported \\
H7: Entrepreneurial orientation has mediates the relationships between transactional \\
leadership and organizational performance
\end{tabular}

\section{Discussion and implications}

This study was to investigate the relationship between Transformational Leadership, Transactional Leadership, Entrepreneurial Orientation and Organizational Performance of SMEs in the manufacturing, and service \& other sectors in Malaysia. The results revealed that more male $(54.4 \%)$ than female $(45.6 \%)$ respondents participated in this study. The majority of the respondents had degree education at $57.9 \%$, and in the age group of 31 to 40 years at $38.7 \%$. The results indicated that respondents possessed higher education has displayed leadership behavior and tend to achieve better performance in business. This is in line with a study done by Karadag (2017) highlighted that education level of owner/managers has affected the financial performances of the business in SMEs. Matama (2016) also stated the levels of education had a significant relationship with financial performance, as more small business owners advanced in education, the more of financial worth was observed in small business firms. The small business owners who had university degrees had more financial knowledge compared to those with secondary and lower education levels (Matama, 2016). This could be attributed to the fact that owners that attained college education may able to understand and analyzing the financing documentation especially the loan contracts and the associated risks unlike the owners with secondary education and below.

The results indicated that the transformational leadership has a significant effect on the organizational performance of SMEs. This is in line with previous studies by Arham (2014), Lim (2016), and Abdul Aziz et al. (2013). Therefore, the entrepreneurs in Malaysia is suggested to practice both forms of leadership behavior and this consistent with the suggestion made by Abdul Aziz et al. (2013) and Ismail et al. (2010). They stated that the leaders that practiced both transformational and transactional leadership behavior effectively will increase positive individual outcomes and lead to increase the organizational performance. 
The result of this study also found that entrepreneurial orientation also partially mediates the relationship between leadership behavior and organizational performance. This signifies that the development of entrepreneurial orientation is the important elements besides leadership behavior in order to increase the organizational performance.

\section{Managerial Implications}

The key objective of this study is to show the consequences which can benefit and practical for SMEs in the manufacturing and service industries. Effective leadership behavior of owners and top managers and entrepreneurial orientation are essential elements that affected the growth and profitability of the firms. Moreover, leaders of SME establishments in these industries are encouraged to understand the complex interaction between their leadership behavior and the level of entrepreneurial orientation practiced in their organization.

\section{Theoretical Contributions}

Modification version of the Questionnaire (MLQ) for the transformational leadership construct also indicate that the factor structure for the transformational leadership construct of the MLQ cannot be retained. Due to low factor loadings and cross-loading resulting in the removal of the individualized influenced factor (I specifically mentioned the importance of having a strong sense of purpose). Other scholars, Arham (2014) and Ozaralli (2003) had to removed factor idealized consideration from the final analysis as well.

\section{Conclusion}

Every study has the limitation. Among the limitations facing when conducting the study was time and situational constraints. This study relied on self-reported data from single informants which may exaggerate their assessment and judgment of their leadership behavior, firms' EO, and organizational performance.

In conclusion, the managers or owners of the business must understand the leadership behavior they display and practice has significant direct and indirect (through EO) contributions to organizational performance. This study doesn't have any intention or suggestion that leaders should practice a particular form of leadership behavior, but empirical findings indicate that when transformational leadership is practiced, it exerts stronger effects on EO and organizational outcomes than transactional leadership does.

\section{References}

Abdul, A. R. et al, (2013). The effect of leadership styles on the business performance of SMEs in Malaysia. International Journal of Economics Business and Management Studies, 2(2), (May, 2013), 45-52.

Abdullah \& Rosli. (2016). An evaluation on determinants of SMEs performance in Malaysia. South East Asia Journal of Contemporary Business, Economics and Law, 7(2), (August) ISSN2289-1560.

Abe, M., Troilo, M., Juneja, J. S., \& Narain, S. (2012). Policy guidebook for SME development in Asia and the Pacific, United Nations ESCAP, Bangkok.

Abu Bakar, H. et al (2016). Effect of entrepreneurial orientation, learning orientation, strategic improvisation on SMEs Performance. Proceedings of IASTEM International Conference, Jakarta, Indonesia, 4th-5th October 2016, ISBN: 978-93-86083-34-0.

Abu Bakar, J., Mad, C. A., \& Abdul, L. R. (2006). Liberalization and globalization: A case of Naza and a lesson to SME, Paper presented at Persidangan Kebangsaan IKS (National Conference of SME) 2006, Kuala Lumpur.

Ahmad, N. H., \& Seet, P. S. (2009). Dissecting behaviours associated with business failure: a qualitative study of SME owners in Malaysia and Australia. Asian Social Science, 5(9), 98-104. https://doi.org/10.5539/ass.v5n9p98

Al-Dhaafri, H. S., Al-Swidi, A. K., \& Yusoff, R. Z. (2016). The mediating role of total quality management between the entrepreneurial orientation and the organizational performance. The TQM Journal, 28(1), 89-111. https://doi.org/10.1108/TQM-03-2014-0033

Alkahtani, A. H., Abu-Jarad, I., Sulaiman, M., \& Nikbin, D. (2011). The impact of personality and leadership styles on leading change capability of Malaysian managers. Australian Journal of Business and Management Research, 1(2), 70-99.

Amin, M. et al (2016). The effect of market orientation as a mediating variable in the relationship between entrepreneurial orientation and SMEs performance. Nankai Business Review International, 7(1), 39-59. https://doi.org/10.1108/NBRI-08-2015-0019 
Amirul, S. R., \& Daud, N. (2012). A study on the relationship between leadership styles and leadership effectiveness in Malaysian GLCs. European Journal of Business and Management, 4(8), 193-202.

Arham, A. F. (2014). Leadership and performance. The case of Malaysian SMEs in the service sector. International Journal of Asian Social Science, 4(3), 343-355.

Arham, A. F. et al (2015). The effect of leadership on entrepreneurial orientation: An online survey on Malaysian SMEs. International Journal of Latest Research in Science and Technology, 4(5), 47-50.

Arshad, A. S. et al (2016). A Transformational Leadership and Business Performance: An Insight From Technology-based SMEs in Malaysia. BE-ci (2016).Presented at 3rd International Conference on Business and Economics, 21-23 September, 2016. https://doi.org/10.15405/epsbs.2016.11.02.5

As-Sadeq, H., \& Khoury, G. (2006). Leadership styles in the Palestinian large scale industrial enterprises. Journal of Management Development, 25(9), 832. https://doi.org/10.1108/02621710610692043

Avolio, B. J. (1999). Full leadership development: building the vital forces in organizations, Sage, Thousand Oaks, CA.

Awang, Z. (2015). SEM made simple: A gentle approach to learning Structural Equation Modeling.

Awang, Z., Afthanorhan, A., Mohamad, M., \& Asri, M. A. M. (2015). An evaluation of measurement model for medical tourism research: the confirmatory factor analysis approach. International Journal of Tourism Policy, 6(1), 29-45. https://doi.org/10.1504/IJTP.2015.075141

Bass, B. M. (1985). Leadership and Performance Beyond Expectations, The Free Press, New York.

Bass, B. M. (1999). 'Two decades of research and development in transformational leadership'. European Journal of Work and Organizational Psychology, 8(1), 9-32. https://doi.org/10.1080/135943299398410

Bollen, K. A. (1989). Structural Equations with Latent Variables, John Wiley \& Sons, Inc, New York. https://doi.org/10.1002/9781118619179

Covin, J. G., \& Slevin, D. P. (1989). Strategic management of small firms in hostile and benign environments. Strategic Management Journal, 10(1), 75-87. https://doi.org/10.1002/smj.4250100107

Dvir, T., Eden, D., Avolio, B. J., \& Shamir, B. (2002). Impact of transformational leadership on follower development and performance: A field experiment. Academy of Management Journal, 45, 735-744.

Dzomonda, O. et al (2016). The impact of leadership styles on the entrepreneurial orientation of Small and Medium Enterprises in South Africa.

Eyal, O., \& Kark, R (2004). How do transformational leaders transform organizations? A study of the relationship between leadership and entrepreneurship. Leadership and Policy in Schools, 3(3), 211-235. https://doi.org/10.1080/15700760490503715

Fornell, C., \& Larcker, D. (1981). Structural equation models with unobservable variables and measurement error. Journal of Marketing Research, 18(1), 39-50. https://doi.org/10.2307/3151312

Gul, S., Ahmad, B., Rahman, S. U., Shabir, N., \& Razzaq, N. (2012). Leadership styles, turnover intentions and the mediating role of organizational commitmen. Information and Knowledge Management, 2(7), 44-51.

Hair Jr, J. F., Babin, B. J., \& Krey, N. (2017). Covariance-Based Structural Equation Modeling in the Journal of Advertising: Review and Recommendations. Journal of Advertising, 1-15.

Hair, J. F., Anderson, R. E., Babin, B. J., \& Black, W. C. (2010). Multivariate data analysis: A global perspective (Vol. 7). Upper Saddle River, NJ: Pearson.

Hande, K. (2017). The impact of industry, firm age and education level on financial management performance in small and medium-sized enterprises (SMEs): Evidence from Turkey. Journal of Entrepreneurship in Emerging Economies, 9(3), 300-314. https://doi.org/10.1108/JEEE-09-2016-0037

Hannay, M. (2009). The cross-cultural leader: The application of servant leadership theory in the international setting. Journal of International Business and Cultural Studies, 1, 1-12.

Hashim, M. K., Ahmad, S. A., \& Zakaria, M. (2012). A study on leadership styles in SMEs. Paper presented at International Conference on Islamic Leadership-2 (ICIL 2), The Royale Chulan, Kuala Lumpur, 26-27 September.

Hassim, A., Abdul, T. A., \& Abu Bakar, A. (2011). The Effects of Entrepreneurial Orientation on Firm Organisational Innovation and Market Orientation towards Firm Business Performance', paper presented to 
International Conference Sociality and Economic Development, Singapore.

Hayat, N., \& Riaz, M. T. (2011). The Influence of the SMES Top-Level Managers Leadership Styles and Their Entrepreneurial Orientation on the Business Performance. SSRN eLibrary, Available at SSRN: http://ssrn.com/abstract=1884069.

Hilmi, M. F., Ramayah, T., Mustapha, Y., \& Pawanchik, S. (2010). Product and process innovativeness: Evidence from Malaysian SMEs. European Journal of Social Sciences, 16(4), 547-555.

Hoq, M. Z., Ha, N. C., \& Said, S. M. (2009). SMEs in the Malaysian economy. International Journal of Marketing Studies, 1(2), 3-17. https://doi.org/10.5539/ijms.v1n2p3

Ireland, R. D., \& Hitt, M. A. (2005). Achieving and maintaining strategic competitiveness in the 21st century: The role of strategic leadership. Academy of Management Executive, 19(4), 65-77. https://doi.org/10.5465/ame.2005.19417908

Ismail, A., Mohamad, M. H., Mohamed, H. A. B., Rafiussin, N. M., \& Zhen, K. W. P. (2010). Transformational and transactional leadership styles as a predictor of individual outcomes. Theoretical and Applied Economics, 17(6), 89-104.

Kashif, M., Samsi, S. Z. M., Awang, Z., \& Mohamad, M. (2016). EXQ:Mmeasurement of healthcare experience quality in Malaysian settings: A contextualist perspective. International Journal of Pharmaceutical and Healthcare Marketing, 10(1), 27-47. https://doi.org/10.1108/IJPHM-03-2015-0011

Kheng Y. K. et al (2013).The determinant of innovative work behavior in yhe knowledge intensive business service sectors in Malaysia. Asian Social Sciences, 9(15), 47-59.

Kihara, P. et al (2016). Relationship between leadership styles in strategy implementation and performance of Small and Medium Manufacturing Firms in Thika Sub-County, Kenya. International Journal of Humanities and Social Science, 6(6), June 2016.

Kraus, S. et al (2012). Entrepreneurial orientation and the business performance of SMEs: A quantitative study from the Netherlands. Rev Management Science, 6, 161-182. https://doi.org/10.1007/s11846-011-0062-9

Kwasi, D. (2015). Resillent leadership: A transformational-transactional leadership mix. Journal of Glbal Responsibility, 6(1), 99-122. https://doi.org/10.1108/JGR-07-2014-0026

Lawal, A. A., Ajonbadi, H. A., \& Otokiti, B. O. (2014). Leadership and organisational performance in the Nigeria Small and Medium Enterprises (SMEs). American Journal of Business, Economics and Management, 2(5), 121-127.

Leung, S. O. (2011). A Comparison of Psychometric Properties and Normality in 4-, 5-, 6-, and 11-Point Likert Scales. Journal of Social Service Research, 37, 412-421. https://doi.org/10.1080/01488376.2011.580697

Lim, C. S. (2016). An investigation of leadership styles and leadership outcomes of Malaysian managers working in the wholesale subsector of the distributive trade sector. DBA thesis, Southern Cross University, Lismore, NSW.

Limsila, K., \& Ogunlana, S. O. (2008) Performance and Leadership Outcome Correlates of Leadership Style And subordinate Commitment. Engineering, Construction and Architectural Management, 15, 164-184. https://doi.org/10.1108/09699980810852682

Ling, Y., Simsek, Z., Lubatkin, M. H., \& Veiga, J. F. (2008). Transformational leadership's role in promoting corporate entrepreneurship: Examining the CEO-TMT interface. Academy of Management Journal, 51(3), 557-576. https://doi.org/10.5465/amj.2008.32626023

Lo, M. C., Ramayah, T., Hii, W. M., \& Songan, P. (2010). The relationship between leadership styles and organizational commitment in Malaysia: role of leadermember exchange. Asia Pacific Business Review, 16(1/2), 79103. https://doi.org/10.1080/13602380903355676

Lumpkin, G. T., \& Dess, G. G. (1996). Clarifying the entrepreneurial orientation Construct and linking it to performance. The Academy of Management Review, 21(1), 135-72. Lumpkin. https://doi.org/10.5465/amr.1996.9602161568

Lumpkin, G. T., \& Dess, G. G. (2001). Linking two dimensions of entrepreneurial orientation to firm performance: The moderating role of environment and industry life cycle. Journal of Business. https://doi.org/10.1016/S0883-9026(00)00048-3

Lussier, R. N., \& Achua, C. F. (2007). Leadership practices inventory: Facilitator'sGuide. 3rd ed. San Francisco. 
Luu, T. T. (2017). Ambidextrous leadership, entrepreneurial orientation and operational performance. Organisational social capital as a moderator. Leadership and Organisation Development Journal, 38(2), 229-252. https://doi.org/10.1108/LODJ-09-2015-0191

Madanchian, M. et al (2016). The relationship between ethical leadership, leadership effectiveness and organizational performance: A review of literature in SMEs context. European Business \& Management, 2(2), 17-21.

Martin, J. (2015). Transformational and Transactional Leadership: An Exploration of Gender, Experience, and Institution Type. Portal Libraries \& the Academy, 15, 331-351. https://doi.org/10.1353/pla.2015.0015

Matzler, K., Schwarz, E., Deutinger, N., \& Harms, R. (2008). 'elationship between transformational leadership, product innovation and performance in SMEs. Journal of Small Business and Entrepreneurship, 21(2), 139-152. https://doi.org/10.1080/08276331.2008.10593418

McKelvie, A., \& Wiklund, J. (2010). Advancing firm growth research: A focus on growth mode instead of growth rate. Entrepreneurship Theory and Practice, 34(2), 261-288. https://doi.org/10.1111/j.1540-6520.2010.00375.x

Miller, D. (1983). The correlates of entrepreneurship in three types of firms. Management Science, 29(7), 770-791. https://doi.org/10.1287/mnsc.29.7.770

Miller, D., \& Friesen, P. H. (1982). Innovation in conservative and entrepreneurial firms: Two models of strategic momentum. Strategic Management Journal, 3(1), 1-25. https://doi.org/10.1002/smj.4250030102

Mohamed, E. E. et al (2017). Relationship of Spirituality Leadership Style and SMEs Performance in Halal Supply Chain. International Journal of Supply Chain Management. IJSCM, ISSN: 2050-7399.

Mohd, A. N. (2007). SMEs: Building blocks for economic growth. Journal of the Department of Statistics Malaysia, 1, 1-13.

Mohd, S. M. F., Tahir, M. N. H., \& Abu, B. K. (2012). 'Owner-manager of SMEs in IT sector: Leadership and company performance'. International Journal of Business and Social Science, 3(14), 195-205

Moreno, A. M., \& Casillas, J. C. (2008). Entrepreneurial orientation and growth of SMEs: A causal mode'. Entrepreneurship Theory and Practice, 32(3), 507-528. https://doi.org/10.1111/j.1540-6520.2008.00238.x

Muhammad, S. B., \& Rosli, M. (2014). Linking Transformational Leadership and Corporate Entrepreneurship to Performance in the Public Higher Education Institutions in Malaysia. Advances in Management and Applied Economics, SCIENPRESS Ltd, 4(3), 1-8.

Naeem, H., \& Tayyeb, M. R. (2011). The Influence of the SMES Top-Level Managers. Leadership Styles and Their Entrepreneurial Orientation on the Business Performance. https://doi.org/10.2139/ssrn.1884069

Nahavandi, A. (2006). The art and science of leadership ((4th ed). Upper Saddle River, NJ: Pearson Education, Inc.

Naman and Slevin (1993). Entrepreneurship and the Concept of Fit: A Model and Empirical Tests. Strategic Management Journal, 14(2), 137-153. https://doi.org/10.1002/smj.4250140205

Nunnally, J. C., \& Bernstein, I. H. (1994). The assessment of reliability. Psychometric theory, 3(1), 248-292. NSDC 2008, SME Annual Report 2008: Rising to Meet Global Challenges, National SME Development Council, Kuala Lumpur.

Ozaralli, N. (2003).Effects of transformational leadership on empowerment and team effectiveness. Leadership \& Organization Development Journal, 24(6), 335-344. https://doi.org/10.1108/01437730310494301

Panagopoulos, N. G., \& Avlonitis, G. J. (2010). Performance implications of sales strategy: the moderating effects of leadership and environment. International Journal of Research in Marketing, 27(1), 46-57. https://doi.org/10.1016/j.ijresmar.2009.11.001

Radam, A., Abu, M. L., \& Abdullah, A. M. (2008). Technical efficiency of small and medium enterprise in Malaysia: a stochastic frontier production model. International Journal of Economics and Management, 2(2), 395-408.

Rauch, A., Wiklund, J., Lumpkin, G. T., \& Frese, M. (2009). Entrepreneurial orientation and business performance: An assessment of past research and suggestions for the future. Entrepreneurship Theory and Practice, 33(3), 76187. https://doi.org/10.1111/j.1540-6520.2009.00308.x

Rodríguez-Gutiérrez, M. J. et al (2013), Entrepreneurial orientation in small firms - values-attitudes-behavior 
approach. International Journal of Entrepreneurial Behaviour \&amp; Research, 19(6), 611-632. https://doi.org/10.1108/IJEBR-10-2012-0106

Runyan, R. C., Ge, B., Dong, B., \& Swinney, J. L. (2012). Entrepreneurial orientation in cross-cultural research: Assessing measurement invariance in the construct. Entrepreneurship Theory and Practice, July, 819-836. https://doi.org/10.1111/j.1540-6520.2010.00436.x

Saleh, A. S., \& Ndubisi, N. O. (2006). An evaluation of SME development in Malaysia. International Review of Business Research Papers, 2(1), 1-14.

Samad, N. A. (2007). Positioning Malaysian SMEs in the global. Paper presented at Persidangan Kebangsaan IKS (National Conference of SME) 2007 Kota Kinabalu.

Sekaran, U., \& Bougie, R. (2010) Research Methods for Business: A Skill Building Approach, 5th edn, John Wiley \&Sons, United Kingdom.

Sekaran, U., \& Bougie, R. (2013) Research Methods for Business-A Skill Building Approach. 6th Edition, John Wiley and Sons, West Sussex.

Steensma, H. K., Marino, L., \& Weaver, K. M. (2000). The influence of national culture on the formation of technology alliances by entrepreneurial firms. Academy of Management Journal, 43(5), 951.

Todorovic, W., \& Schlosser, F. K. (2007). An entrepreneur and a leader. A framework conceptualizing the influence of leadership style on a firm's entrepreneurial orientation - performance relationship. Journal of Small Business and Entrepreneurship, 20(3), 289-308. https://doi.org/10.1080/08276331.2007.10593401

Wang, C. L. (2008).'Entrepreneurial orientation, learning orientation, and firm performance. Entrepreneurship Theory and Practice, 32(4), 635-657. https://doi.org/10.1111/j.1540-6520.2008.00246.x

Wiklund, J. (1999). The sustainability of the entrepreneurial orientation--performance relationship. Entrepreneurship: Theory \& Practice, 24(1), 39-50. https://doi.org/10.1177/104225879902400103

Wiklund, J., \& Shepherd, D (2005). Entrepreneurial orientation and small business performance: A configurational approach'. Journal of Business Venturing, 20(1), 71-91. https://doi.org/10.1016/j.jbusvent.2004.01.001

Yang, C. W. (2008). The relationships among leadership styles, entrepreneurial orientation, and business performance'. Managing Global Transitions, 6, 257.

Yogeswaran (2015). Theses Pengaruh Gaya Kepimpinan, Kompetensi Pengurusan dan Orientasi Keusahawanan Terhadap Prestasi Perniagaan Kecil dan Sederhana (PKS) Usahawan India.

Yulk, G. (2010). Leadership in Organizations. 7th edn, Prentice-hall, New Jersey.

Zumitzavani, V., \& Udchachone, S. (2014). The Influence of Leadership Styles on Organisational Performance Mediated by Organisational Innovation: A Case Study of the Hospitality Industry in Thailand. International Conference on Economics, Management and Development.

\section{Copyrights}

Copyright for this article is retained by the author(s), with first publication rights granted to the journal.

This is an open-access article distributed under the terms and conditions of the Creative Commons Attribution license (http://creativecommons.org/licenses/by/4.0/). 